\title{
A multi-technique study for the spectroscopic characterization of the ceramics from Santa Maria do Castelo church (Torres Novas, Portugal)
}

\author{
L.F. Vieira Ferreira ${ }^{\text {a,* }}$, M. Varela Gomes ${ }^{\text {b }}$, M.F.C. Pereira ${ }^{\text {c }}$ L.F. Santos ${ }^{\mathrm{d}}$, I. Ferreira Machado ${ }^{\text {a,e }}$

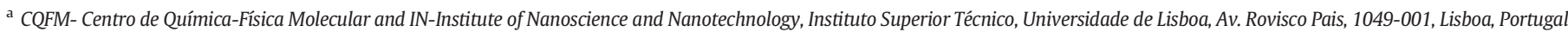 \\ b Instituto de Arqueologia e Paleociências da Universidade Nova de Lisboa, Departamento de História, Avenida de Berna 26-C, 1069-061, Lisboa, Portugal \\ c CERENA- Centro de Estudos em Recursos Naturais e Ambiente, Instituto Superior Técnico, Universidade de Lisboa, Av. Rovisco Pais, 1049-001, Lisboa, Portugal \\ ' CQE- Centro de Química Estrutural, Instituto Superior Técnico, Universidade de Lisboa, Av. Rovisco Pais, 1049-001, Lisboa, Portugal \\ e Polytechnic Institute of Portalegre, P-7300-110, Portalegre, Portugal
}

\section{A R T I C L E I N F O}

\section{Article history:}

Received 1 October 2015

Received in revised form 15 January 2016

Accepted 8 February 2016

Available online $\mathrm{xxxx}$

\section{Keywords:}

Portuguese ancient ceramics

XRD

$\mathrm{XRF}$

Micro-Raman

GSDR

\begin{abstract}
A B S T R A C T
An excavation in a 14th c. church at Torres Novas, named Santa Maria do Castelo, provided some green glazed ceramic sherds, archaeologically dated from 14 th c. to the 16 th c. The town of Torres Novas is located at the center of Portugal, about $100 \mathrm{~km}$ north of Lisbon.

The obtained results evidence three types of pastes of the pottery: type 1 with Quartz, Illite, Muscovite and Microcline as the main constituents, type 2 with Quartz, Calcite and Gehlenite; and finally type 3 with Quartz, Calcite and Diopside being the major components. Type 1 pastes are related to clay sources of Pliocene origin, and all this pottery was most probably made in Portuguese kilns. However, types 2 and 3 spectroscopic trends are remarkably different, indicating that those ceramics were produced in Seville.

All the studied ceramics are lead glazed, and green glazed. In one of the samples from the Seville kiln, Cerusite was the main pigment used to obtain the greenish colouration.

In what regards the origin of all samples produced with Pliocene clays, the 16th c. ones were most likely produced in the Santo António da Charneca or Mata da Machada kilns, both located in the south shore of the Tagus river, region of Lisbon. In what regards the green glazed jug rim (14th c.) and the jug spout (15th c.) they could also have been produced in the two mentioned kilns south of Lisbon city, but another interesting hypothesis - due to richness of the decoration - is the production in Lisbon workshops, with the use of Pliocene clays imported by Lisbon potters, now documented both in Lisbon archaeological findings and also in documental sources.
\end{abstract}

(C) 2016 Elsevier Ltd. All rights reserved.

\section{Introduction}

Archaeological excavations made in 2004 and 2011 in the remains of the Medieval church of Santa Maria do Castelo (Torres Novas), at the centre of Portugal, and about $100 \mathrm{~km}$ north of Lisbon, provided many different finds. Among those there are some green glazed pottery sherds, dated from the 14th century (the time when the church was built) and others from the 15th-16th centuries.

Among the older objects there is a jar rim fragment with a tall neck, decorated with vertical lines printed with a roller (sample SMC1, Fig. 1). This type of decoration technique was largely used in the Saintonge productions (Southwest of France) and in some Flanders pottery workshops during the Middle Ages.

This archaeological site also provided sherds of tiles with HispanoMoresque decoration (Vieira Ferreira et al., 2014), imported from Seville at the beginning of the 16th c., where the tin glazed technique was already in use. It is well known that Hispano-Moresque tiles were widely

\footnotetext{
* Corresponding author.

E-mail address: Ifvieiraferreira@tecnico.ulisboa.pt (L.F.V. Ferreira).
}

spread in Portugal at the end of the 15th c., and especially during the 16th c., due to a significant importation from Seville (Triana kilns) under the Portuguese King Manuel the 1st (Vieira Ferreira et al., 2014). Many of these tiles covered the walls of the royal Palace of Sintra and others were used in the decoration of many churches and monasteries spread all over the country.

No medieval kilns are known in the area of Torres Novas, but other kilns producing tin glaze or lead glaze wares are well known in the region of Lisbon, and were located either in the city of Lisbon or in the south shore of the Tagus river at Santo António da Charneca (SAC) and Mata da Machada (MM), both active from the end of the 15th century to the mid-16th century (Torres, 1990; Carmona and Santos, 2005; Barros et al., 2012; Gaspar and Gomes, 2012; Mangucci, 1996; Vieira Ferreira et al., 2015b).

The sherds from this excavation site were studied with the use of non-invasive spectroscopies, namely by correlating information obtained with different techniques: Ground State Diffuse Reflectance absorption (GSDR), micro-Raman and X-Ray Fluorescence emission (XRF). X-Ray Diffraction (XRD) experiments were also performed. This multidisciplinary approach to the archaeometric study of Portuguese 
SMC 1

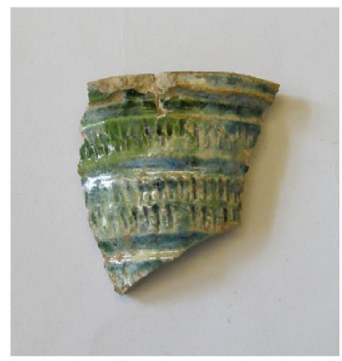

SMC 4

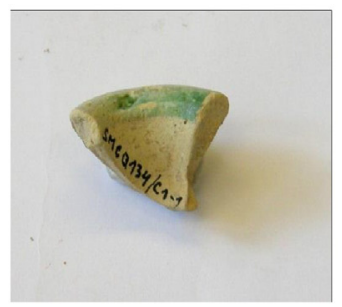

SMC 2

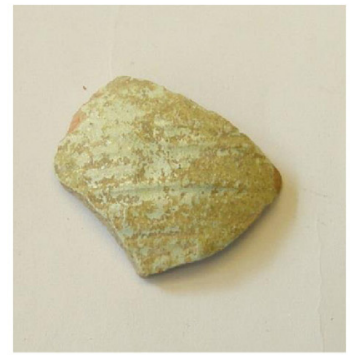

SMC $5,6,7$

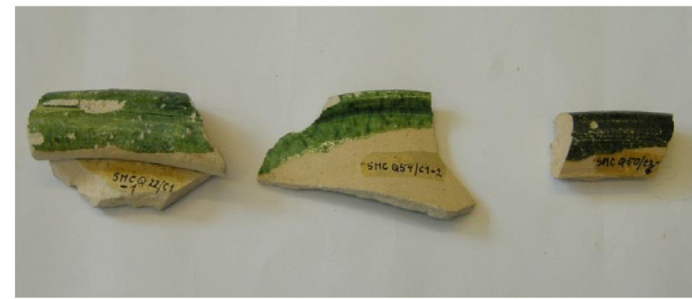

$\mathrm{SMC3}$

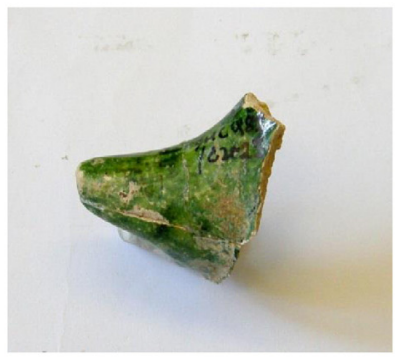

Fig. 1. Ceramic sherds from Sta Maria do Castelo's excavation. faiences was recently applied to 16 th and 17 th c. ceramics by our group (Vieira Ferreira et al., 2013a, 2013b, 2015a).

Micro-Raman is probably the most powerful non-destructive method to characterize archaeological artefacts, namely glazed ceramics and coloured glasses, and has been extensively used to investigate ancient ceramic art objects (de Waal, 2004, 2009; Colomban, 2003, 2005, 2006, 2008, 2010, 2012). Micro-Raman can be used to obtain information regarding the crystalline or glassy structures, which are built from covalent bonds between the $\mathrm{SiO}_{4}$ tetrahedra in different modes. The ratio of the stretching (i.e. $\sim 1000 \mathrm{~cm}^{-1}$ ) and bending $\left(\sim 500 \mathrm{~cm}^{-1}\right)$ Raman envelopes, measured as the band area ratio $\left(I_{p}=A_{500} / A_{1000}\right)$, where $I_{p}$ is the polymerization index proposed by Colomban $(2003,2005,2006,2008,2012)$ can be correlated to the temperature of the kiln, glaze composition and different fluxing agents. Also the correlation of the polymerization index $\mathrm{I}_{\mathrm{p}}$ with the $\mathrm{\Omega}$ stretching maximum $\left(\nu_{\max }\right)$ may provide information regarding the glaze composition (Kırmızı et al., 2010; Colomban et al., 2010).

$\mathrm{X}$-ray diffraction analysis (XRD) is also a very important technique that may provide complementary information to micro-Raman spectroscopy for the characterization of pottery (Vieira Ferreira et al., 2014; Ballirano et al., 2014; Porras et al., 2012), and is especially useful for the study of the crystalline phases of the ceramic pastes. In many cases pastes from clay minerals exhibit weak or complex Raman signals, and XRD may provide useful information concerning the detailed mineralogical composition of a ceramic body, by using a diffraction pattern database (Vieira Ferreira et al., 2014).

$\mathrm{X}$-ray fluorescence (XRF) was used here due to the availability of portable instruments, although it only allows the determination of elemental compositions for elements heavier than sodium. It is also a very important tool for determining chemical compositions (Simsek et al., 2014).

The main objectives of this study are the mineralogical and spectroscopic characterization of the pastes, glazes and pigments of the archaeological material found at Santa Maria do Castelo. Glazes will be compared, and the temperature of the firing process of the kiln will be analysed, aiming to distinguish the different productions of the ceramics found in excavation of this church.

The spectroscopic results obtained here for the samples SMC1 to SMC7 were compared with the findings reported in previous works (Vieira Ferreira et al., 2013b, 2014, 2015b), for pottery and tiles from two kilns located in the South shore of Tagus river (Santo António da Charneca and Mata da Machada, 15th and 16th c.), as well as from Lisbon and Seville pottery productions from the 16th c. Santo António da Charneca and Mata da Machada used in most cases local raw materials of Pliocene origin, while Lisbon kilns used Miocene clays. Two main types of pastes (or its mixture) were detected in the Lisbon productions and were characterized from a mineralogical and spectroscopic point of view (Vieira Ferreira et al., 2015b). Significant differences from the Triana (Seville) Miocene origin pastes were found.

\section{Experimental}

\subsection{Spectroscopic tools under use}

Micro-Raman spectroscopy, ground-state diffuse reflectance set-up, X-ray fluorescence spectrometry, and X-ray diffraction techniques used in this work are described below.

\subsubsection{Micro-Raman spectrometry set-up}

Micro-Raman measurements were carried out in a back-scattering micro-configuration, with two instruments: i) a homemade apparatus with a Cobolt solid state laser, continuum wave, model Samba, $300 \mathrm{~mW}, 532 \mathrm{~nm}$ as the excitation source, coupled to an Olympus microscope, model BX-FM, equipped with $10 \times, 50 \times$ or $100 \times$ Olympus LWD objectives. The laser beam was focused on a diameter of about 25,5 and $1.5-2 \mu \mathrm{m}$ respectively. The Raman probe was coupled to an Andor monochromator (Shamrock 163 with a $100 \mu \mathrm{m}$ entrance slit), and a Newton DU 971P-BV camera from Andor was used as the detector for the Raman signals, working at $-60{ }^{\circ} \mathrm{C}$ (Vieira Ferreira et al., 2013a, 2014, 2015a). ii) A LabRam HR Evolution, from Horiba - Jobin Yvon, was also used in some cases for more detailed spectral information, with a $532 \mathrm{~nm}$ excitation source. The light was focused with a $50 \times$ LWD or a $100 \times$ objective and the laser power on the sample was approximately $10 \mathrm{~mW}$. Spectra were acquired using 10 s of signal collection time and 5 accumulations. Two gratings were used, 600 or 1200 groves per $\mathrm{mm}$, depending on the spectral resolution needed, $120 \mathrm{~cm}^{-1}$ to $3600 \mathrm{~cm}^{-1}$ or $100 \mathrm{~cm}^{-1}$ to $1760 \mathrm{~cm}^{-1}$, respectively. The spectral resolution of the Raman spectrometers was $\sim 4 \mathrm{~cm}^{-1}$ when using the 600 groves' grating, and $\sim 2 \mathrm{~cm}^{-1}$ when using the 1200 groves' grating. All Raman spectra were recorded at least 5 times for each 
sample in different locations, and all spectra presented in this paper are representative (Vieira Ferreira, 2013a, 2014, 2015a).

Data acquisition was performed with the Andor software and data processing, namely the baseline correction, when needed, it was done with the LabSpec software from JY.

\subsubsection{Ground state diffuse reflectance spectra (GSDR)}

Ground-state absorption studies were performed using a homemade diffuse reflectance laser flash photolysis setup, with a $250 \mathrm{~W}$ WHal lamp as monitoring lamp, triggering the system in the normal way but without the laser fire (Vieira Ferreira and Ferreira Machado, 2007). In this way the lamp profile was recorded for all samples under study and also for two standards: the barium sulfate powder and a Spectralon disk. A fixed monochromator - coupled to an ICCD with time gate capabilities - was used for detecting the reflectance signals (Vieira Ferreira and Ferreira Machado, 2007). The reflectance, R, from each sample was obtained in the UV-Vis-NIR spectral regions, and the remission function, $\mathrm{F}(\mathrm{R})$, was calculated by using the Kubelka-Munk equation for optically thick samples. The remission function is $F(R)=$ $(1-R)^{2} / 2 R$. Details regarding the data treatment can be found in (Vieira Ferreira and Ferreira Machado, 2007) and the references quoted therein.

\subsubsection{X-ray fluorescence experiments}

The chemical composition of ceramic glazes and pastes was also accurately determined by X-ray fluorescence with the use of a Niton XL3T GOLDD spectrometer from Thermo Scientific with an X-ray generator of $50 \mathrm{kV} / 200 \mu \mathrm{A}$, equipped with a CCD for image location ( $3 \mathrm{~mm}$ spot diameter) and storage (Vieira Ferreira et al., 2013a, 2014, 2015a).

\subsubsection{X-ray diffraction experiments}

The identification of the ceramic body powder crystalline phases was carried out with an X-Ray diffractometer at CERENA (Panalytical X'PERT PRO model) by using $\mathrm{CuK} \alpha$ radiation. The measurement parameters used were: $2 \theta\left(5-65^{\circ}\right)$; step size $2 \theta=0.033^{\circ}$ and a scan step time of $80 \mathrm{~s}$ with generator settings of $35 \mathrm{~mA}$ and $40 \mathrm{kV}$. The analysis was performed with the program High Score Plus by using the PDF4 data base.

In the case of XRD measurements only about $10 \mathrm{mg}$ of powder sample were used to perform an experiment.

\subsection{Studied materials}

Fig. 1 shows the representative samples selected for this work, SMC1 to SMC7. All samples except SMC2 are green glazed. SMC2 is whitish/ greenish, and apparently non-glazed. All sherds have dimensions of about 4-5 cm except in case SMC2 where the dimension is about $2 \mathrm{~cm} \times 3 \mathrm{~cm}$. SMC1 is a jar rim fragment with a tall neck, decorated with vertical lines printed with a roller, and SMC3, another pitcher spout fragment seems to present similar fabrics and glaze. SMC4 a third rim fragment, also from a jar, and SMC2 is a fragment from a bottle's body decorated with horizontal cannelures. SMC5 and SMC7 are basin rims and SMC6 is a fragment from a plate.

The choice of the earthenware sherds SMC1 to SMC7 was based on the fact that they were found in secure and well dated archaeological contexts (samples SMC1 and SMC3 are from the 14th c., samples SMC2 and SMC4 from the 15th c., and samples SMC5 to SMC7 from the 16 th c.). Sherds were recovered from the church archaeological site or from the surrounding waste areas and dated based on archaeological stratigraphy.

\subsection{Characterization studies}

GSDR, Micro-Raman and XRF are non-invasive spectroscopies and were applied directly onto the glaze or the paste of the sherd. In the XRD case, about $10 \mathrm{mg}$ of the ceramic's body were needed for the pastes' study. Those small amounts of powder were removed from the sherds and used for the XRD determinations, i.e. the pastes' mineralogical characterization, by drilling the sherds' edge with a $1 \mathrm{~mm}$ tungsten carbide drill, coupled to a small electric drill.

The LabRaman equipment has accurate confocal capabilities, enabling in depth studies from the surface to about $200 \mu \mathrm{m}$ deep, but the penetration depth doesn't go over 50-70 $\mu \mathrm{m}$ in most cases, depending on the coloured glaze under study. For XRF the estimated penetration depth is about $60 \mu \mathrm{m}$ for Pb glazes. For the GSDR studies all the glaze depth was analysed due to the use of a powerful W-Hal lamp (250 W).

\section{Results and discussion}

\subsection{XRD studies}

Fig. 2 shows the XRD experimental patterns for pastes of Santa Maria do Castelo ceramics SMC1 to SMC7. The XRD peaks were assigned to: Quartz (Q, $\mathrm{SiO}_{2}$, main peaks at $2 \theta=21.0,26.7,36.7,46.0,50.2,60.0$ ), Gehlenite $\left(\mathrm{G}, \mathrm{Ca}_{2} \mathrm{Al}(\mathrm{AlSi}) \mathrm{O}_{7}\right.$, main peaks at $2 \theta=24.3,29.3,31.4,37.2$, $44.5,52.2,61.3)$, Diopside $\left(\mathrm{D}, \mathrm{CaMgSi}_{2} \mathrm{O}_{6}\right.$, main peaks at $2 \theta=29.9$, $30.5,31.0,35.1,35.7)$, Anorthite $\left(\mathrm{An}, \mathrm{CaAl}_{2} \mathrm{Si}_{2} \mathrm{O}_{8}\right.$, main peaks a $2 \theta=$ $22,28)$, Calcite $\left(\mathrm{C}, \mathrm{CaCO}_{3}\right.$, main peaks at $\left.2 \theta=29.4,47.5\right)$, Muscovite $\left(\mathrm{M}, \mathrm{KAl}_{2}\left(\mathrm{Si}_{3} \mathrm{Al}\right) \mathrm{O}_{12}(\mathrm{OH})_{2}\right.$, with main XRD peaks at $2 \theta=8.8,17.8,26.7$, 45.3), Microcline (Mic, $\mathrm{KAlSi}_{3} \mathrm{O}_{8}$, main peak at $2 \theta=27.3$ ), Analcime (Anl, $\mathrm{NaAlSi}_{2} \mathrm{O}_{6} \cdot \mathrm{H}_{2} \mathrm{O}$, main peaks at $2 \theta=15.9,26.3$ ) and Illite (I, main peaks at $2 \theta=8.8,19.7,27,35)$. All these assignments were made by the use of the High Score Plus software from Panalytical and PDF4

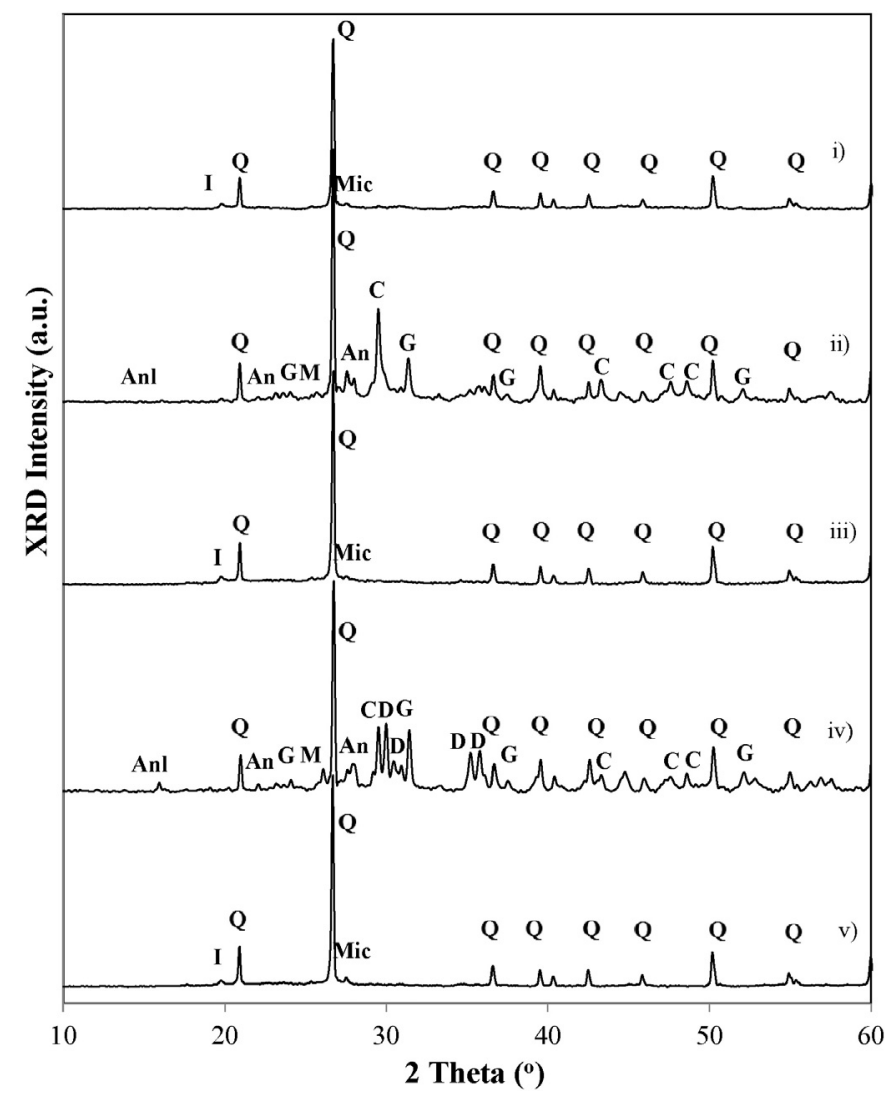

Fig. 2. Representative XRD patterns for pastes from Santa Maria do Castelo samples: i) SMC1, jug side, 14th c.; ii) SMC2, jug sherd, Islamic, 15th c.; iii) SMC3, jug spout, 14th c.; iv) SMC4, jug side, 15 th c.; v) SMC5 sherd from a basin, 16th c.; the XRD peaks are assigned to: Quartz (Q), Gehlenite (G), Diopside (D), Anorthite (An), Calcite (C), Analcime (Anl), Illite (I), Muscovite (M) and Microcline (Mic). 
database, and simultaneously by the use of the RRUFF database (accessed in May 2015).

From a mineralogical standpoint the main features to point out are the following: the pastes from the sherds SMC1, SMC3 and SMC5 to 7 are quite similar and most probably they were made with the use of raw materials from the same clay source. Similar XRD patterns were published recently by our group for a tile from Alhos Vedros church and small ceramic sherds from Santo António da Charneca (SAC) and Mata da Machada (MM) (Vieira Ferreira et al., 2014, 2015b). The dominating mineral is Quartz, although small amounts of Microcline and of Illite could also be detected, as curves i), iii) and v) from Fig. 2 show. Illite is decomposed at $600{ }^{\circ} \mathrm{C}$ into amorphous phases (metakaolin, etc). Thus Illite Bragg peaks may occur due to soil contamination.

Certainly the clays used in these ceramics had the same origin, i.e. the Pliocene raw materials that exist in that region, south of the Tagus river and close to Lisbon city (Vieira Ferreira et al., 2014, 2015b; Zbyszewski, 1963; Lepierre, 1899; Carvalho, 1921). All the ceramic pastes from Santo António da Charneca and most from Mata da Machada exhibit the same mineralogical pattern, and only differences in the iron oxide content were observed, the more iron oxide the darker the raw material (Vieira Ferreira et al., 2014, 2015b).

The use of Pliocene clays (rich in Quartz, Kaolinite, Illite, Muscovite and Microcline) to produce the ceramics' pastes is a very specific and original feature. In previous published work (Vieira Ferreira et al., 2013b, 2015b) coeval ceramics from Triana (Seville), Valencia and others were studied. The diffractogram obtained for these ones, resemble the Miocene clays from the Lisbon clay sources (Vieira Ferreira et al., 2015b), however with specific differences in the calcium carbonate contents and also Andradite absence.

These results are in clear contrast with SMC2 and SMC4 sherds, both using different raw materials in the ceramic productions. As one can see, the XRD patterns for the sherds ii) and iv) evidence a high amount of Calcite (main peaks at $2 \theta=29.4,47.5$ ) which did not exist in the ceramics with Pliocene clay materials (Vieira Ferreira et al., 2014, 2015b). Sample SMC4 exhibits Quartz, Diopside (or Augite, which XRD peaks are almost identical to those of Diopside), and Anorthite as the main mineral constituents. In sample SMC2, the rim jug sherd, Gehlenite is more relevant than Diopside.

These diffractograms present some similarity with the Lisbon XRD patterns described in a previous paper (Vieira Ferreira et al., 2015b), although with a remarkable difference: no $\mathrm{CaCO}_{3}$ exists in the Lisbon pottery from this period or exist only in very small amounts; also the relative amounts of Diopside and Gehlenite are different. Andradite is common in Lisbon pastes but not in the Seville productions. Therefore we conclude that different clays (raw materials) were used in SMC2 and SMC4 for the ceramic productions, and that these ceramics were not produced in the Lisbon workshops. In fact, a comparison with the pastes of 16th c. tiles produced in Seville, recently reported by our group (Vieira Ferreira et al., 2014), shows that the pastes of SMC2 and SMC4 are Seville productions. The two diffractograms for the two Seville tiles are presented in Figs. S1 and S2 for comparison. For Seville tile patterns references (Betts and Weinstein, 2010; Meco, 1989; Pleguezuelo, 1996) are indicated.

\subsection{XRF studies}

XRF is a sensitive, non-destructive elemental analysis technique using a sub-millimetre or millimetre scale respectively, which allows for a quantification of elements between magnesium and uranium which may exist in the samples under study from major to trace levels. All the analyses both on pastes and glazes were performed, at least, in three spots of about $3 \mathrm{~mm}$ in diameter of the sherd, but in most cases five spots for each sample. In the cases where the pastes' analysis was performed in a powdered sample, at least three essays were also done (Vieira Ferreira et al., 2014, 2015b; Simsek, 2014). Apart the internal calibration, the equipment was calibrated with standards IRRM-BCR-126A
- Lead Crystal Glass, and BAM-S005B - Multi-element Glass for XRF Analysis.

Table 1 presents the chemical composition of the ceramic pastes for the samples under study, obtained by XRF analysis, expressed as weight $\%$ of the indicated oxides (or recalculated to $100 \mathrm{wt} . \%$ as sum of the different oxides). Representative XRF spectra are depicted in Fig. 3, obtained with an acquisition time of $360 \mathrm{~s}$ for each spectrum.

The elemental compositions of the ceramic bodies as well as the spectra allow us to considered two main groups of samples: samples SMC1 and SMC3 present a similar overall composition. Both pastes present a $\mathrm{SiO}_{2}$ content of $\sim 75 \mathrm{wt} . \%$ and $\mathrm{Al}_{2} \mathrm{O}_{3} \sim 17 \mathrm{wt} \%$ (amount of $\mathrm{SiO}_{2}+\mathrm{Al}_{2} \mathrm{O}_{3} \sim 90 \mathrm{wt} . \%$ ). The calcium oxide content is very small (less than 1 wt.\%) in samples SMC 1 and SMC 3. By opposite, the $\mathrm{Fe}_{2} \mathrm{O}_{3}$ content varies between 3 and 4\%. For samples SMC5, SMC6 and SMC7 the $\mathrm{SiO}_{2}$ and the $\mathrm{Al}_{2} \mathrm{O}_{3}$ contents together are also about 90 wt.\% with almost no calcium oxide ( $0.6-0.7 \mathrm{wt} . \%)$. The iron oxide content does not exceed 3.5 wt.\%. Very similar ceramic bodies' composition patterns were already observed by us in previous studies (Vieira Ferreira et al., 2014, 2015b).

Samples SMC2 and SMC4 are part of a second group which presents a $\mathrm{SiO}_{2}$ content below $50 \mathrm{wt}$.\% and very high calcium oxide content, lying in a range 27-34 wt.\%. These samples showed the lowest $\mathrm{SiO}_{2}$ content (with an amount of $\mathrm{SiO}_{2}+\mathrm{Al}_{2} \mathrm{O}_{3}$ of about $60 \mathrm{wt}$.\%) and the highest calcium oxide content of all samples in this study.

In what regards the coloured glaze phases, their chemical composition is presented in Table 2 for samples under study.

Apart from sample SMC2, which presents a very low $\mathrm{PbO}$ content (below $11 \mathrm{wt} . \%$ ), we observed that the major components of the glazes are $\mathrm{SiO}_{2}$ and $\mathrm{PbO}$ resulting in ca $70-80 \%$ of the overall glaze's composition as is the case of lead based glazes. However, the silica content is quite different. In samples SMC5 and SMC6, the silica content is below 30 wt.\% and the $\mathrm{PbO} / \mathrm{SiO}_{2}$ ratio is the highest $\left(\mathrm{PbO} / \mathrm{SiO}_{2} \sim 2.0-2.4\right)$. In SMC1 and SMC3 the silica content is below 40 wt.\% and the $\mathrm{PbO} / \mathrm{SiO}_{2}$ ratio 1.2-1.6. Samples SMC2 and SMC4 present the highest silica content (45-56 wt.\% $\mathrm{SiO}_{2}$ ) and a $\mathrm{PbO} / \mathrm{SiO}_{2}$ ratio smaller than 1.0. A common observation for all samples is that almost no $\mathrm{SnO}_{2}$ was detected in all the glazes under study (very low amounts $0.02-0.1 \mathrm{wt} . \%$ ).

Another important observation, depicted in Table 2, is that copper seems to be responsible for the green pigment in all studied samples. Apart from the SMC2 sample, the copper oxide content lays in the range $3-5 \mathrm{wt} . \%$, and no chromium was detected. This statement is in agreement with the ground sate absorption spectra of the glazes, as we will show later in this paper.

Table

Chemical composition for the pastes for all earthenware sherds determined by the use of XRF, wt.\%. nd: not detected; nq: not quantified.

\begin{tabular}{|c|c|c|c|c|c|c|c|}
\hline & SMC1 & SMC2 & SMC3 & SMC4 & SMC5 & SMC6 & SMC7 \\
\hline $\mathrm{MgO}$ & nd/nq & 2.31 & $\mathrm{nd} / \mathrm{nq}$ & $\mathrm{nd} / \mathrm{nq}$ & nd/nq & $\mathrm{nd} / \mathrm{nq}$ & $\mathrm{nd} / \mathrm{nq}$ \\
\hline $\mathrm{Al}_{2} \mathrm{O}_{3}$ & 17.84 & 11.43 & 21.09 & 11.06 & 26.27 & 22.00 & 12.03 \\
\hline $\mathrm{SiO}_{2}$ & 73.63 & 49.21 & 70.79 & 43.72 & 66.63 & 72.11 & 78.98 \\
\hline $\mathrm{P}_{2} \mathrm{O}_{5}$ & 0.25 & nd/nq & $\mathrm{nd} / \mathrm{nq}$ & 1.34 & nd/nq & nd/nq & $\mathrm{nd} / \mathrm{nq}$ \\
\hline $\mathrm{K}_{2} \mathrm{O}$ & 1.93 & 2.67 & 1.82 & 1.77 & 2.02 & 1.89 & 3.32 \\
\hline $\mathrm{CaO}$ & 0.84 & 27.85 & 0.54 & 33.42 & 0.69 & 0.63 & 1.47 \\
\hline $\mathrm{TiO}_{2}$ & 1.17 & 0.99 & 1.11 & 0.61 & 0.92 & 0.99 & 1.04 \\
\hline $\mathrm{Cr}_{2} \mathrm{O}_{3}$ & 0.01 & $\mathrm{nd} / \mathrm{nq}$ & 0.02 & $\mathrm{nd} / \mathrm{nq}$ & 0.02 & $\mathrm{nd} / \mathrm{nq}$ & $\mathrm{nd} / \mathrm{nq}$ \\
\hline $\mathrm{MnO}$ & $\mathrm{nd} / \mathrm{nq}$ & 0.07 & $\mathrm{nd} / \mathrm{nq}$ & 0.12 & nd/nq & $\mathrm{nd} / \mathrm{nq}$ & $\mathrm{nd} / \mathrm{nq}$ \\
\hline $\mathrm{Fe}_{2} \mathrm{O}_{3}$ & 3.08 & 4.44 & 4.33 & 6.56 & 3.33 & 2.30 & 3.01 \\
\hline $\mathrm{NiO}$ & 0.24 & $\mathrm{nd} / \mathrm{nq}$ & $\mathrm{nd} / \mathrm{nq}$ & $\mathrm{nd} / \mathrm{nq}$ & $\mathrm{nd} / \mathrm{nq}$ & $\mathrm{nd} / \mathrm{nq}$ & 0.04 \\
\hline $\mathrm{CuO}$ & 0.07 & 0.05 & 0.02 & 0.13 & $\mathrm{nd} / \mathrm{nq}$ & $\mathrm{nd} / \mathrm{nq}$ & $\mathrm{nd} / \mathrm{nq}$ \\
\hline $\mathrm{ZnO}$ & $\mathrm{nd} / \mathrm{nq}$ & 0.01 & 0.01 & 0.01 & nd/nq & $\mathrm{nd} / \mathrm{nq}$ & 0.01 \\
\hline $\mathrm{Rb}_{2} \mathrm{O}$ & 0.00 & 0.01 & 0.01 & 0.01 & 0.01 & 0.01 & 0.01 \\
\hline $\mathrm{SrO}$ & 0.00 & 0.02 & 0.01 & 0.04 & 0.01 & 0.01 & 0.00 \\
\hline $\mathrm{ZrO}_{2}$ & 0.01 & 0.03 & 0.03 & 0.04 & 0.02 & 0.03 & 0.02 \\
\hline $\mathrm{SnO}_{2}$ & $\mathrm{nd} / \mathrm{nq}$ & $\mathrm{nd} / \mathrm{nq}$ & $\mathrm{nd} / \mathrm{nq}$ & $\mathrm{nd} / \mathrm{nq}$ & nd/nq & $\mathrm{nd} / \mathrm{nq}$ & $\mathrm{nd} / \mathrm{nq}$ \\
\hline $\mathrm{PbO}$ & 0.94 & 0.92 & 0.24 & 1.17 & 0.07 & 0.03 & 0.07 \\
\hline
\end{tabular}




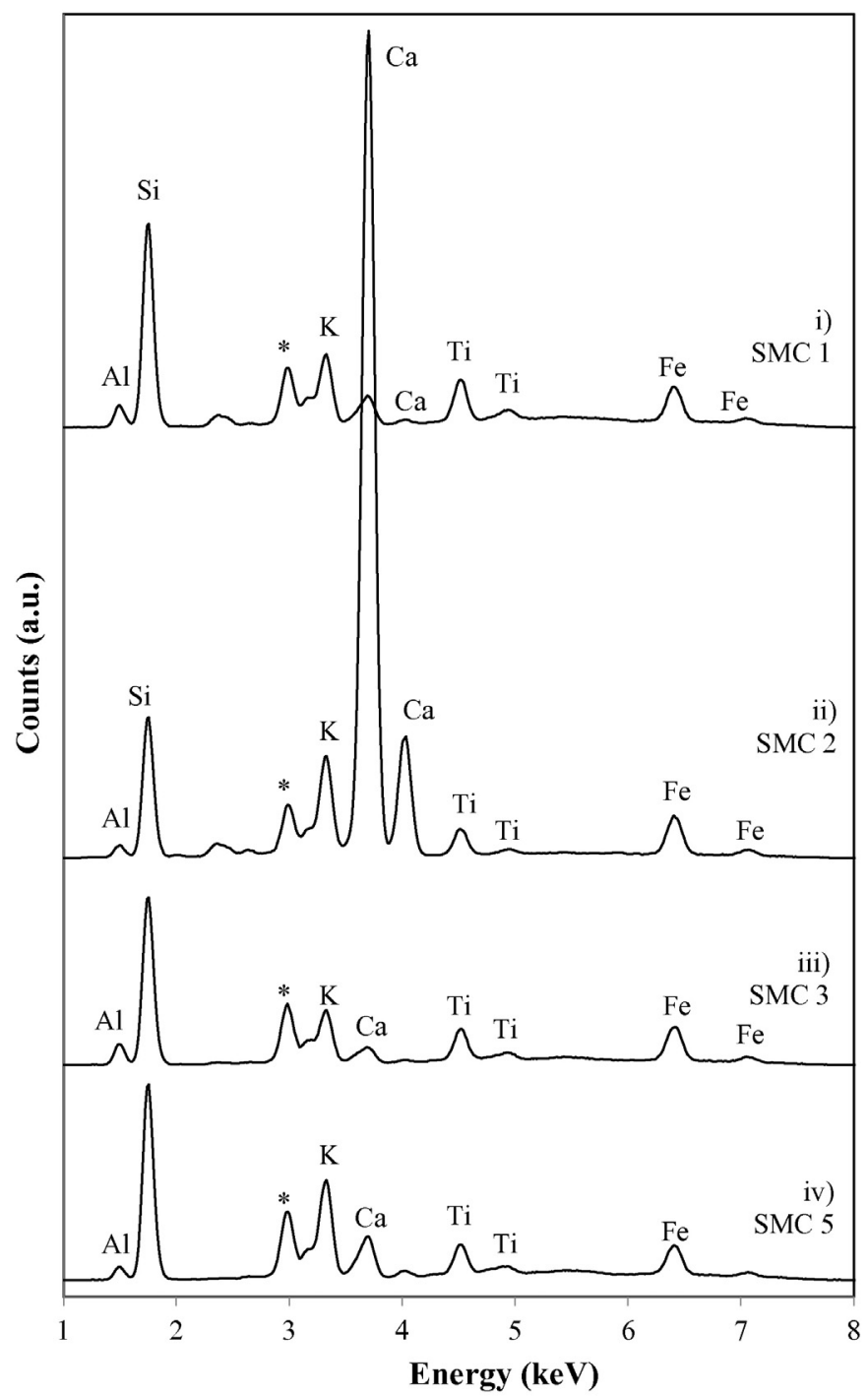

* Represents the emission line from the X-ray tube

Fig. 3. Representative X-ray fluorescence spectra (1-8 keV energy range) for pastes from Santa Maria do Castelo samples: i) SMC1, jug side, 14th c.; ii) SMC2, Islamic bottle sherd, 15th c.; iii) SMC3, jug spout, 14th c.; iv) SMC5, sherd from a basin, 16th c.; the XRF peaks are assigned to: Silicium (Si), Iron (Fe), Potassium (K), Calcium (Ca), and Titanium (Ti). *Refers to the silver cathode of the XRF system.

\subsection{Raman microspectroscopic studies}

Micro-Raman spectroscopy is a very useful technique not only in the identification of pigments and analysis of the glazes at the sherds' surface but also for the analysis of pastes. These information are of particular importance when correlated with the XRD diffractograms. The micro-Raman spectra were obtained for all different sherds from SMC ceramics under study and are shown in Fig. 4i) to $\mathrm{x}$ ).

Raman spectra of SMC1 green glaze (jug spout, 14th c.) is shown in Fig. 4 i) and exhibits clear signatures of Quartz (peaking at 202, 352, 463 and $805 \mathrm{~cm}^{-1}$ ), and also of Anatase peaking at 145, 393, 512 and $634 \mathrm{~cm}^{-1}$ ). These bands are superimposed in the bending band of the silica glaze, and the stretching band is much larger, peaking at $959 \mathrm{~cm}^{-1}$, a common value for lead based glazes (Colomban, 2003, $2005,2006,2008,2012$ ). The ratio of the $\mathrm{SiO}_{2}$ stretching and bending Raman envelopes gave an $\mathrm{I}_{\mathrm{p}}$ value of about 0.4 , and from this value we can estimate the kiln's temperature to be $\sim 750{ }^{\circ} \mathrm{C}$, as proposed by Colomban. The absence of Rutile is in accordance with the estimated temperature of the kiln, since only for temperatures above $900{ }^{\circ} \mathrm{C}$, does Anatase start to be transformed into Rutile (Simsek et al., 2014).

Another aspect to be mentioned is the absence of tin oxide $\left(\mathrm{SnO}_{2}\right.$, peaking at 475,633 and $775 \mathrm{~cm}^{-1}$ ) usually used as a whitening agent in the white and green glazes of the Santo António da Charneca tiles, and in the white faience of Mata da Machada, also produced with the use of Pliocene clay materials.

For the body (Fig. 4 ii)) this sherd reveals the same crystalline materials, Quartz and Anatase, however the stretching and the bending bands of the glaze are absent, as expected. In some sherds of this pottery obtained from Pliocene clay sources, small amounts of the clays of the initial raw material, Kaolinite, Illite and Muscovite may remain as the XRD data showed, but they rarely can be observed by Raman spectrometry (Vieira Ferreira et al., 2014).

The ceramics were normally fired twice: the first one to go from the initial raw materials to the biscuit and the second are to produce the coloured glaze. Since we are dealing with very simple ceramics, with one colour only, no further firing was needed in these cases.

In what regards the green glaze we could not observe it's signature in all the SMC samples under study here. XRF indicates the presence of a copper mineral as being responsible for the green colour. $\mathrm{Cu}^{2+}$ ions are dissolved in the glaze matrix, producing the green colour of the glaze, in spite of non-being detected by micro-Raman. The use of micro FT-IR spectroscopy also failed in the tentative identification of the initial used copper pigment. Moreover this assignment could be made with the use of the ground state absorption spectra presented later in Fig. 5.

In the Islamic sherd SMC2, the whitish/greenish cover (Fig. 4 iii)) exhibits a very clear Raman signature from lead carbonate, Cerussite (C, $\mathrm{PbCO}_{3}$ peaking at 148, 175, 213, 681, 838, 1054, 1376 and $1478 \mathrm{~cm}^{-1}$ ). The very light green colour of this glaze is certainly associated with presence of this mineral, certainly formed by reaction of the sample's calcium carbonate with the lead oxide added for the glaze formation. The paste (Fig. 4 iv)) shows the presence of Anatase, Calcite ( $\mathrm{Cal}, \mathrm{CaCO}_{3}$, peaking at 273, 710 and $1086 \mathrm{~cm}^{-1}$, and a clear signature of Carbon Black (CB, 1325 and $\sim 1580 \mathrm{~cm}^{-1}$ ). Gehlenite signature, which XRD diffractogram presented before proved to exist in this paste, could hardly be identified in this paste, its main Raman peaks being located at 230, 308, 620,662, 911 and $955 \mathrm{~cm}^{-1}$.

Sample SMC3 paste (Fig. $4 \mathrm{vi}$ )) is essentially the same as the SMC1 paste (Fig. 4 ii)), This shows again the use of the same clays in both

Table 2

Chemical composition for the coloured glazes and pigments or all earthenware sherds determined by the use of XRF, wt.\%. nd: not detected; nq: not quantified.

\begin{tabular}{|c|c|c|c|c|c|c|c|}
\hline & SMC 1 & SMC 2 & SMC 3 & SMC 4 & SMC 5 & SMC 6 & SMC 7 \\
\hline & $\overline{\text { Green }}$ & Whitish/greenish & $\overline{\text { Green }}$ & $\overline{\text { Green }}$ & $\overline{\text { Green }}$ & $\overline{\text { Green }}$ & Green \\
\hline $\mathrm{MgO}$ & $\mathrm{nd} / \mathrm{nq}$ & 2.22 & 4.19 & $\mathrm{nd} / \mathrm{nq}$ & $\mathrm{nd} / \mathrm{nq}$ & $\mathrm{nd} / \mathrm{nq}$ & $\mathrm{nd} / \mathrm{nq}$ \\
\hline $\mathrm{Al}_{2} \mathrm{O}_{3}$ & 9.76 & 9.88 & 12.47 & 6.69 & 10.84 & 9.15 & 11.02 \\
\hline $\mathrm{SiO}_{2}$ & 33.98 & 56.65 & 32.30 & 45.47 & 22.91 & 26.02 & 43.83 \\
\hline $\mathrm{P}_{2} \mathrm{O}_{5}$ & 6.00 & 1.81 & 1.71 & 2.78 & 2.35 & 2.17 & 2.59 \\
\hline $\mathrm{K}_{2} \mathrm{O}$ & 0.60 & 0.93 & 0.73 & 2.08 & 0.25 & 0.60 & 0.49 \\
\hline $\mathrm{CaO}$ & 2.07 & 11.65 & 1.22 & 4.20 & $\mathrm{nd} / \mathrm{nq}$ & 0.00 & $\mathrm{nd} / \mathrm{nq}$ \\
\hline $\mathrm{TiO}_{2}$ & 0.10 & 0.44 & 0.08 & 0.20 & $\mathrm{nd} / \mathrm{nq}$ & 0.09 & 0.18 \\
\hline $\mathrm{Cr}_{2} \mathrm{O}_{3}$ & $\mathrm{nd} / \mathrm{nq}$ & $\mathrm{nd} / \mathrm{nq}$ & $\mathrm{nd} / \mathrm{nq}$ & $\mathrm{nd} / \mathrm{nq}$ & $\mathrm{nd} / \mathrm{nq}$ & $\mathrm{nd} / \mathrm{nq}$ & $\mathrm{nd} / \mathrm{nq}$ \\
\hline $\mathrm{MnO}$ & 0.24 & 0.08 & 0.18 & 0.15 & 0.20 & 0.16 & 0.20 \\
\hline $\mathrm{Fe}_{2} \mathrm{O}_{3}$ & 0.64 & 3.63 & 0.42 & 1.65 & 0.53 & 0.51 & 0.95 \\
\hline $\mathrm{CoO}$ & $\mathrm{nd} / \mathrm{nq}$ & $\mathrm{nd} / \mathrm{nq}$ & $\mathrm{nd} / \mathrm{nq}$ & $\mathrm{nd} / \mathrm{nq}$ & 0.00 & $\mathrm{nd} / \mathrm{nq}$ & $\mathrm{nd} / \mathrm{nq}$ \\
\hline $\mathrm{NiO}$ & 0.06 & $\mathrm{nd} / \mathrm{nq}$ & 0.06 & $\mathrm{nd} / \mathrm{nq}$ & 0.05 & 0.07 & 0.04 \\
\hline $\mathrm{CuO}$ & 2.78 & 0.51 & 2.10 & 2.31 & 1.96 & 3.03 & 5.68 \\
\hline $\mathrm{ZnO}$ & 0.03 & 0.00 & $\mathrm{nd} / \mathrm{nq}$ & $\mathrm{nd} / \mathrm{nq}$ & $\mathrm{nd} / \mathrm{nq}$ & 0.17 & $\mathrm{nd} / \mathrm{nq}$ \\
\hline $\mathrm{As}_{2} \mathrm{O}_{3}$ & 4.62 & 1.43 & 3.17 & 2.61 & 4.95 & 5.18 & 3.87 \\
\hline $\mathrm{Rb}_{2} \mathrm{O}$ & $\mathrm{nd} / \mathrm{nq}$ & 0.01 & $\mathrm{nd} / \mathrm{nq}$ & $\mathrm{nd} / \mathrm{nq}$ & $\mathrm{nd} / \mathrm{nq}$ & $\mathrm{nd} / \mathrm{nq}$ & $\mathrm{nd} / \mathrm{nq}$ \\
\hline SrO & $\mathrm{nd} / \mathrm{nq}$ & 0.02 & $\mathrm{nd} / \mathrm{nq}$ & $\mathrm{nd} / \mathrm{nq}$ & $\mathrm{nd} / \mathrm{nq}$ & $\mathrm{nd} / \mathrm{nq}$ & $\mathrm{nd} / \mathrm{nq}$ \\
\hline $\mathrm{ZrO}_{2}$ & $\mathrm{nd} / \mathrm{nq}$ & $\mathrm{nd} / \mathrm{nq}$ & $\mathrm{nd} / \mathrm{nq}$ & $\mathrm{nd} / \mathrm{nq}$ & $\mathrm{nd} / \mathrm{nq}$ & $\mathrm{nd} / \mathrm{nq}$ & $\mathrm{nd} / \mathrm{nq}$ \\
\hline $\mathrm{SnO}_{2}$ & $\mathrm{nd} / \mathrm{nq}$ & 0.02 & $\mathrm{nd} / \mathrm{nq}$ & 0.06 & 0.10 & $\mathrm{nd} / \mathrm{nq}$ & 0.11 \\
\hline $\mathrm{PbO}$ & 39.12 & 10.71 & 41.38 & 31.80 & 55.88 & 52.85 & 31.03 \\
\hline
\end{tabular}




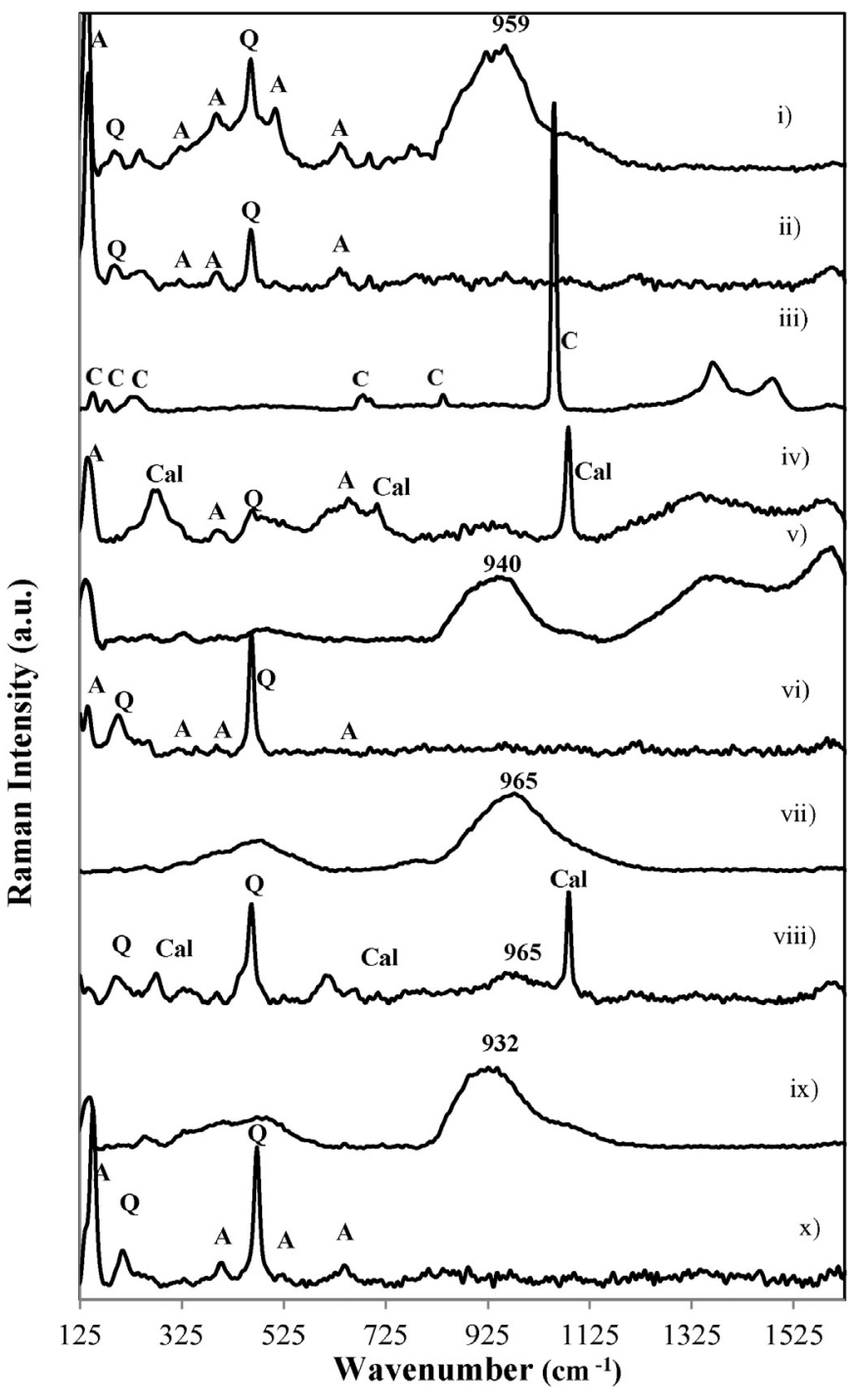

Fig. 4. Representative Raman spectra of the Santa Maria do Castelo sherds, both for pastes and green glazes. i) SMC1, green glaze; ii) SMC1, paste; iii) SMC2, whitish/greenish cover; iv) SMC2, paste; v) SMC3, green glaze; vi) SMC3, paste; vii) SMC4, green glaze; viii) SMC4, paste; ix) SMC5, green glaze; $x)$ SMC5, paste. The Raman signals are assigned to: anatase $(A)$, quartz $(Q)$, cerusite $(C)$ and calcite $($ Cal).

ceramics. In what regards the glaze (Fig. 4 v)) the main difference in this case is due to the existence of Carbon Black in larger amounts. The temperature of the kiln also seems to be lower than in case SMC1, curve i).

Raman spectrum of the paste of SMC4 sample, the top edge of the green jug, is shown in Fig. 4 viii) and is quite similar to the paste of sample SMC2, revealing a high content of Quartz and Calcite. Anatase and Carbon Black also exist, although in reduced amounts. Diopside Raman signature, peaking at $318,359,390,664$ and $1011 \mathrm{~cm}^{-1}$ exists in this paste, as revealed by XRD, however it is almost absent as compared to the Quartz and Calcite Raman signatures.

This sherd's green glaze (curve vii) is similar to the previous green glazes of SMC1 and SMC3, although with no Anatase peaks superimposed, and no Carbon Black. The polymerization index is very small for SMC3, $\mathrm{I}_{\mathrm{p}}=0.15$, pointing to the use of the kiln's lowest temperature in all samples under study $\left(\mathrm{T} \sim 650^{\circ}-700^{\circ} \mathrm{C}\right)$.

Finally, only one Raman curve is presented in Fig. 4 for the green glaze (curve ix) and another for the paste (curve $\mathrm{x}$ ) of sample SMC5. The Raman spectra obtained for samples 5, 6 and 7 were the same within experimental error. These samples were stratigraphically dated as 16 th c. samples and indeed they were clearly produced with the same Pliocene raw material from the Santo António da Charneca and
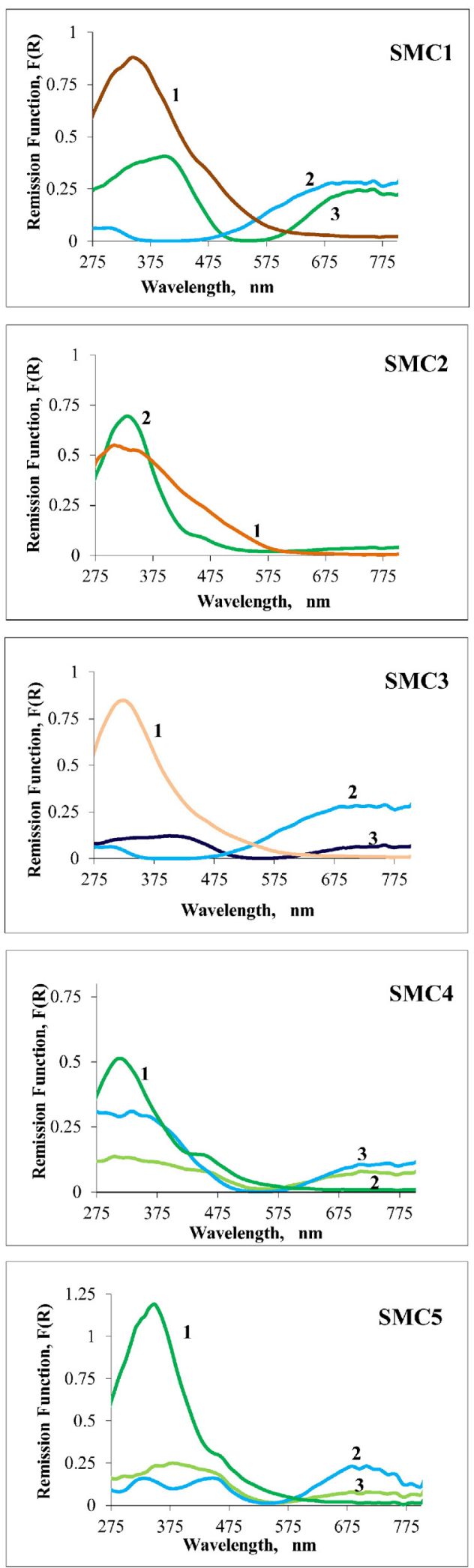

Fig. 5. Representative ground state diffuse reflectance spectra of the Santa Maria do Castelo sherds, both for pastes and green glazes. In all figures 1- paste, 2 - light green glaze, 3 - dark green glaze.

Mata da Machada raw materials. They are only lead glazed, i.e., no tin oxide was used as it was common for the courseware productions of those two kilns. Only tiles and better quality pottery productions 
revealed the use of the faience technique in these two 15th/16th c. kilns, situated south of Lisbon.

One should also stress here the similarity between these 16 th c. productions (samples SMC5, 6 and 7) and the 14th c. (sample SMC1) and 15th c. productions (sample SMC3). There are no reported kilns in the Lisbon city area or in the South of Lisbon area dated 14th c. The discovery of sample SMC1 in the Torres Novas excavation may point to the existence of a kiln dated 14th c. in the region of Mata da Machada and to Santo António da Charneca kilns, or at least to a kiln in another area using the same raw materials characteristic of those two kilns, i.e. the Pliocene kaolinitic sands. A very interesting possibility is that samples SMC1 and SMC3 were produced in Lisbon workshops, since it is now well documented that some workshops from Lisbon imported those Pliocene raw materials from the South shore of the Tagus river (Alho et al., 2015).

\subsection{Ground state diffuse reflectance spectroscopy studies}

The ground state diffuse reflectance absorption spectra could be obtained from the reflectance curves, and also with the use of the Kubelka Munk function $F(R)=(1-R)^{2} / 2 R$, for pastes and coloured glazes of the 14 th $\mathrm{c}$. to 16 th $\mathrm{c}$. ceramics gathered at SMC excavation at Torres Novas. Those results are presented in Fig. 5, SMC1 to SMC5 (for samples SM6 and 7 the results are similar to SM5).

The ground state diffuse reflectance absorption spectra for the ceramics' pastes for the Pliocene clays, SMC1, 3 and 5-7, exhibit a maxima peaking at about $350 \mathrm{~nm}$ with tails in the visible region of the absorption spectra, as Fig. 5 shows (curves 1 are for the pastes). These data are in agreement with similar ones published by our group for the 16 th c. ceramic productions in the region of Lisbon (Vieira Ferreira et al., 2014, 2015b). For the Seville pastes (SMC2 and SMC4) the maxima for these curves are not too different and spread from about $320 \mathrm{~nm}$ to about $350 \mathrm{~nm}$, also with long tails in the visible region of the absorption.

For all samples, except SMC2, the green glaze curves (dark green) exhibit two maxima at about $400 \mathrm{~nm}$ and $750 \mathrm{~nm}$, while for the light green glazes the UV region presents smaller absorptions. This immediately excludes the use of chromium oxide pigments which exhibit absorption peaks at $455 \mathrm{~nm}$ and $636 \mathrm{~nm}$, characteristic of $\mathrm{Cr}^{3+}$ ions (Vieira Ferreira et al., 2014), and is also in agreement with the XRF data presented in Table 2, where the amount of chromium oxide detected is negligible. For all dark green glazes the amount of copper oxide revealed by XRF is significant, pointing to the presence $\mathrm{Cu}^{2+}$ ions as the origin of the green colour. The source of this green pigment is, most probably, basic copper carbonate (Taylor and Doody, 2014), and the absorption spectra presented for the dark green glazes are compatible with this assignment (Vieira Ferreira et al., 2014).

The light green glaze from sample SMC2 differs from the other light and dark glazes, most likely due to the presence of the lead carbonate, and exhibits strong absorption in the UV (max. at about $330 \mathrm{~nm}$ ), while the visible absorption at about $750 \mathrm{~nm}$ is much more moderate.

\section{Conclusions}

Archaeometric studies were recovered from the excavation of Santa Maria do Castelo 14th c. church at Torres Novas. The obtained results were compared with those obtained from 16th c. Portuguese ceramics, either tiles and pottery sherds from Santo António da Charneca's kiln or sherds from Mata da Machada's kiln (Vieira Ferreira et al., 2014, 2015b) or even with tiles of Spanish provenance, namely from the Triana kilns of Seville (Vieira Ferreira et al., 2014; Betts and Weinstein, 2010). The latter tiles (Hispano-Moresque) were found in this excavation at Santa Maria do Castelo church and were imported in the beginning of the 16 th c. from Seville in large quantities, and are commonly found in Portuguese territory.

By the use of the mineralogical composition for the pastes obtained from the XRD diffractograms, and also from the spectroscopic characterization presented here for pastes and green glazes, we conclude that five of the seven sherds studied here were produced with the use of Pliocene clays (south of Lisbon clay sources) and could have been produced either in the Santo António da Charneca or in the Mata da Machada kilns (end-15th to mid-16th c.). However, since the Lisbon workshops also used clay materials from the south bench of the Tagus river (Vieira Ferreira et al., 2015b), Lisbon workshops are very good candidates for the production of SMC1 and SMC3 samples. The two final sherds, the bottle sherd SMC2 and the jug rim SMC4 are Seville productions. All sherds are lead glazes and no tin oxide was used in their fabrication.

Taking into account the polymerization index, we determined $\mathrm{I}_{\mathrm{p}}=$ 0.4 for the green jug rim from the 14 th c., and slightly smaller $\mathrm{I}_{\mathrm{p}}$ 's for the other green lead glazes $I_{p}=0.15$. In the former case we estimate a $750{ }^{\circ} \mathrm{C}$ kiln temperature and in the latter lead glazes of about $650{ }^{\circ} \mathrm{C}-$ $700{ }^{\circ} \mathrm{C}$.

The archaeometric analysis in this paper indicates that most objects are in fact Portuguese, despite formally similar to North European productions, chemically resembling to productions of the Tagus river south bench. These belong to the same production area of the three SMC5 to SMC7 fragments, although these are later productions. The bottle fragment reveals a Seville origin and easily associated to the wellknown trade of tiles and pottery from that Spanish city during the Middle and Early Modern Ages.

Supplementary data to this article can be found online at http://dx. doi.org/10.1016/j.jasrep.2016.02.013.

\section{Acknowledgements}

Thanks are due to FCT, Portugal, for the funding project UID/NAN/ $50024 / 2013$.

\section{References}

Alho, A.P., Trindade, R., Coentro, S., Muralha, V., 2015. Um olhar sobre a documentação de Setúbal e a azulejaria medieval em Portugal, GlazeArch 2015, LNEC (2nd and 3rd June 2015).

Ballirano, P., De Vito, C., Medeghini, L., Mignardi, S., Ferrini, V., Matthia, P., Bersani, D., Lottici, P.P., 2014. A combined use of optical microscopy, X-ray powder diffraction and micro-Raman spectroscopy for the characterization of ancient ceramic from Ebla (Syria). Ceram. Int. 40, 16409-16419.

Barros, L., Batalha, L., Cardoso, G., Gonzalez, A., 2012. A Olaria Renascentista de Santo António da Charneca - Barreiro, in: Velhos e Novos Mundos Estudos de Arqueologia Moderna. Centro de História de Além-Mar, Lisboa, pp. 699-710.

Betts, I.M., Weinstein, R.I., 2010. Tin-glazed Tiles in London. Published by Museum of London Archaeology, p. 88.

Carmona, R., Santos, C., 2005. Olaria da Mata da Machada: Cerâmica dos Séculos XV e XVI Câmara Municipal do Barreiro 1, 68-73.

Carvalho, J.M.T., 1921. A Cerâmica Coimbrã no século XVI. Impressa da Universidade Coimbra.

Colomban, Ph., 2003. Polymerization degree and Raman identification of ancient glasses used for jewelry, ceramic enamels and mosaics. J. Non-Cryst. Solids 322, 180-187.

Colomban, Ph., 2008. On site Raman identification and dating of ancient glasses: a review of procedures and tools. J. Cult. Herit. 9, e55-e60.

Colomban, Ph., 2012. Pottery, glass and enamelled artefacts: how to extract information on their manufactory technology, origin and age? in: Analytical Archaeometry: Selected Topics; Editors H. Howell, P. Vandenabeele, Chapter 8.

Colomban, Ph., Paulsen, O., 2005. Non-destructive determination of the structure and composition of glazes by Raman spectroscopy. J. Am. Ceram. Soc. 88, 390-395.

Colomban, Ph., Tournie, A., Bellot-Gurlet, L., 2006. Raman identification of glassy silicates used in ceramics, glass and jewellery: a tentative differentiation guide. J. Raman Spectrosc. 37, 841-852.

Colomban, Ph., Milande, V., Le Bilhan, L., 2010. On-site Raman analysis of iznic pottery glazes and pigments. J. Raman Spectrosc. 35, 527-535.

de Waal, D., 2004. Raman investigation of ceramics from 168 and 17th century Portuguese shipwrecks. J. Raman Spectrosc. 35, 646-649.

de Waal, D., 2009. Micro-Raman and portable Raman spectroscopic investigation of the blue pigments in selected Delft plates (17-20th century). J. Raman Spectrosc. 40, 2162-2170.

Gaspar, A., Gomes, A., 2012. A Cerâmica Moderna do Castelo de S. Jorge: produção local de cerâmica comum, pintada a branco, moldada e vidrada e de faiança, in: Velhos e Novos Mundos. Estudos de Arqueologia Moderna. Centro de História de Além-Mar, Lisboa, pp. 719-732.

Kırmızı, B., Colomban, Ph., Quetteb, B., 2010. On-site analysis of Chinese Cloisonn'e enamels from fifteenth to nineteenth centuries. J. Raman Spectrosc. 41, 780-790. 
Lepierre, C., 1899. Estudo Chimico e Technologico sobre a Cerâmica Portuguesa Moderna. Imprensa Nacional, Lisboa.

Mangucci, A., 1996. Olarias de Louça e Azulejo da Freguesia de Santos-o-Velho: dos meados dos séculos XVI aos meados do século XVII, Al-Madan. II Série 5, 155-168.

Meco, J., 1989. O Azulejo em Portugal. Editado por Publicações Alfa SA, Lisboa.

Pleguezuelo, A., 1996. Cerâmicas de Triana: Coleccion Carranza. Seville, Fundatión El Monte.

Porras, A.G., Capelli, C., Cabella, R., Pastor, J.R., Cardell, C., 2012. Ceramic production in Granada and in southeast of the Iberian Peninsula during the late middle ages: clays, tools and pots - some preliminary notes. Medieval Pottery 33, 29-42.

RRUFF project database, http://rruff.info/accessed in March to May 2015

Simsek, G., Casadio, F., Colomban, Ph., Bellot-Gurlet, L., Faber, K.T., Zelleke, G., Milande, V Moinet, E., 2014. On-site identification of early Böttger red stoneware made at Meissen using portable XRF: 1, body analysis. J. Am. Ceram. Soc. 97, 2745-2754.

Taylor, B., Doody, K., 2014. Ceramic Glazes - the Complete Handbook. Thames and Hudson Ltd, London, UK.

Torres, C., 1990. Um forno cerâmico dos séculos XV e XVI na Cintura de Lisboa. Mata da Machada - Barreiro. Fours de Potiers et Testares Médièvaux en Mediterranée occidentale: Métodes et Resultats, Archaeologie XIII. Casa de Velazquez, Madrid, pp. 131-141.

Vieira Ferreira, L.F., Ferreira Machado, I.L., 2007. Surface photochemistry: organic molecules within nanocavities of calixarenes. Curr. Drug Discovery Technol. 4, 229-245.
Vieira Ferreira, L.F., Casimiro, T.M., Colomban, Ph., 2013a. Portuguese tin-glazed earthenware from the 17th century: pigments and glazes characterization. Spectrochim. Acta. Part A 104, 437-444.

Vieira Ferreira, L.F., Ferreira Machado, I., Ferraria, A.M., Casimiro, T.M., Colomban, Ph., 2013b. Portuguese tin-glazed earthenware from the 16th century: a spectroscopic characterization of pigments, glazes and pastes. Appl. Surf. Sci. 285, 144-152.

Vieira Ferreira, L.F., Conceição, D.S., Ferreira, D.P., Santos, L.F., Casimiro, T.M., Ferreira Machado, I., 2014. Portuguese 16th century tiles from Santo António da Charneca's kiln: a spectroscopic characterization of pigments, glazes and pastes. J. Raman Spectrosc. 45, 838-847.

Vieira Ferreira, L.F., Conceição, D.S., Ferreira, D.P., Santos, L.F., Pereira, M.F.C., Casimiro, T.M., Ferreira Machado, I., 2015a. Portuguese tin-glazed earthenware from the 17th century. Part 2: a spectroscopic characterization of pigments, glazes and pastes of the three main production centers. Spectrochim. Acta. Part A 149, 285-294.

Vieira Ferreira, LF, Gonzalez, A, Pereira, M.F.C., Santos, L.F., Casimiro, T.M., Ferreira, D.P. Conceição, D.S., Ferreira Machado, I., 2015b. Spectroscopy of 16th century Portuguese tin-glazed earthenware produced in the region of Lisbon. Ceram. Int. 41, 13433-13446.

Zbyszewski, G., 1963. Carta Geológica dos Arredores de Lisboa. Serviços Geológicos de Portugal. 